\title{
Identification of hydrogeochemical process linked to marine intrusion induced by pumping of a semiconfined mediterranean coastal aquifer
}

\author{
F. Sola $\cdot$ A. Vallejos $\cdot$ L. Moreno $\cdot$ J. A. López Geta $\cdot$ \\ A. Pulido Bosch
}

Received: 23 January 2012/ Accepted: 16 June 2012/Published online: 18 July 2012

(C) CEERS, IAU 2012

\begin{abstract}
This article analyses the hydrogeochemical processes, linked to the freshwater-seawater mixing zone, which can be caused by continuous pumping from a detrital coastal aquifer. It was necessary to construct an experimental plot, drilling three boreholes along a line perpendicular to the coast. A complete physico-chemical analysis was done of all water samples taken. The percentage of seawater, calculated from Chloride and ${ }^{18}$ Oxygen concentrations, varied between 55 and $90 \%$. The ionic deltas $(\Delta)$ calculated, and the saturation indices (SI) of mineral phases susceptible to precipitation or dissolution, allowed a series of hydrogeochemical processes to be identified that occur as a consequence of the advance of marine intrusion into the coastal band, and of aquifer flushing. Based on the major elements, the fraction of exchange $(\beta I)$ was calculated for samples ranging from seawater to freshwater, and this revealed that differences in $\beta I$ could explain the hydrochemistry of the mixing zone. The main processes recognised include precipitation of dolomite, dissolution of gypsum, fixation of sulphur salts and cation exchange. Most of the ion exchange took place between $\mathrm{Na}$ and Calcium + Magnesium ions. The process of fixation or liberation of these ions is probably determined by the advance or recession of the saline wedge, and/or by recharge during rainy periods. The behaviour of Magnesium is more sensitive to small variations in salinity, whilst Calcium behaves more homogeneously. The high percentage of
\end{abstract}

F. Sola $\cdot$ A. Vallejos $(\bowtie) \cdot$ A. Pulido Bosch Department of Hydrogeology, University of Almería, 04120 Almería, Spain

e-mail: avallejo@ual.es

L. Moreno · J. A. López Geta

Spanish Geological Survey, IGME, Ríos Rosas 23, 28003 Madrid, Spain seawater in the samples studied favours the speed and magnitude of processes such as ion exchange, and the intervention of magnesium is also a key.

Keywords Groundwater-seawater relationship . Ionic exchange capacity - Stable isotopes .

Water-rock interaction

\section{Introduction}

Salinization processes affect many coastal aquifers throughout the world, and their effects are especial cause for concern in arid and semiarid regions, where groundwaters are usually scarce and aquifers are subject to overexploitation (el Yaouti et al. 2009; Abdalla et al. 2010). Salinization of coastal aquifers can have a variety of origins: dissolution of evaporites (Xue et al. 2000; Sánchez-Martos et al. 2002a, b; Farber et al. 2007), anthropogenic pollution and infiltration of irrigation returns (Rosenthal et al. 1992; Kass et al. 2005; Ghabayen et al. 2006), and/or seawater intrusion. Many studies have been undertaken on the physical processes occurring at the freshwater-saltwater interface in terms of the flow and transport of miscible fluids of differing density (Bear et al. 1999; Khublaryan et al. 2008; Abd-Elhamid and Javadi 2011). Generally, however, studies based on the hydrochemical processes linked to marine intrusion in coastal aquifers cover quite extensive areas (Kim et al. 2003; Ma et al. 2007; Gattacceca et al. 2009), whilst there are fewer examples of detailed monitoring of hydrogeochemical processes occurring in the freshwater-seawater transition band (Andersen et al. 2005). Thus, much of the knowledge acquired for this aspect has been based on laboratory experiments (Beekman and Appelo 1990; Boluda et al. 2008; Panteleit et al. 2011). 
The processes most commonly studied include cation exchange, redox reactions and processes of dissolution and precipitation of mineral phases linked to changes in position of the mixing zone (Appelo 1994; Appelo and Postma 2005).

Several works have been done around the study area, although the involved issues have been very different: groundwater problems in an broad area where the interaction between detrital aquifers and deep carbonate aquifers determines the quality of water (Pulido-Bosch et al. 1992); processes of natural salinization conditioned by the semi-arid character of the region and characterised by jointly studying the content of various minor ions and a series of ionic relationships (Sánchez-Martos et al. 2002a); assessing water quality by means of self-organising maps (Sánchez-Martos et al. 2002b).

The objective of the current study is to identify the hydrogeochemical processes that take place in the freshwater-seawater transition over the first few metres of the coastal band when pumping is carried out close to the shore. To achieve this, an experimental plot was designed over a coastal detritic aquifer. Recharge of the aquifer comes basically from infiltration through the bed of the ephemeral river and directly from rainfall. Given the semiarid climate of the zone, with precipitation of less than $350 \mathrm{~mm} /$ year (Lázaro et al. 2001), the river bed is dry for most of the year, with a number of floods linked to large storm events. The area is subject to intense agricultural activity in greenhouses, supplied principally from groundwater pumped from this aquifer. This causes negative piezometric levels close to the shoreline which, in turn, encourage seawater intrusion (Jorreto et al. 2009). A further consequence of these abstractions is that the land could be subsiding at a rate of 1-3 mm/year (Pulido-Bosch et al. 2011).

From 2006, a desalination plant has been in operation at the apex of the delta, supplied with seawater from several boreholes. These, along with other deep boreholes, identify the position of the seawater wedge in this centre of the delta, indicating that it penetrates more than $3 \mathrm{~km}$ inland.

The experimental plot is on the left bank of the Andarax delta, in the vicinity of the University of Almería (Fig. 1a). Two control piezometers were drilled and one pumping well, each $70 \mathrm{~m}$ deep and penetrating the whole of the Plioquaternary detrital aquifer horizon. The three boreholes were aligned perpendicular to the coast. The pumping well (P-b), furthest from the coast, lies $27 \mathrm{~m}$ from the shore, whilst the intermediate piezometer (P-1) lies at $25 \mathrm{~m}$, and the piezometer closest to the sea (P-2) at only $4 \mathrm{~m}$ (Fig. 1b). This configuration was designed so that pumping from P-b would favour intrusion and that the flowpaths would be from the sea to the pumping well via the two piezometers. Accordingly, it is feasible to analyse the changes over time in the physicochemical characteristics of the water in this aquifer horizon, from March 2009 to April 2010.

The lithological column established from samples taken during drilling show the presence of a Holocene silty-sandy layer containing abundant bivalve remains in the first $20 \mathrm{~m}$ of aquifer. The following $50 \mathrm{~m}$ correspond to gravels, silts and sands dating from the Plioquaternary, below which lies the impermeable substrate, consisting of Pliocene silts with secondary gypsum. The slotted length of both the pumping well and the piezometers lies between 60 and $70 \mathrm{~m}$ depth. Therefore, it is a multilayer aquifer, partially confined by the silty sands from floodwater which limit the connection with the sea. Well logs undertaken in the 3 boreholes identified a wide band of mixing beneath the first $20 \mathrm{~m}$ of freshwater (Fig. 1b). Given the proximity to the coast, and the non-influenced conditions, the piezometric level lies at close to $0 \mathrm{~m}$, with slight variation due to the tides.

\section{Materials and methods}

The experiment was carried out on the delta of the river, overlying a multilayer aquifer in which the existence of low-transmissivity strata semi-confine the main aquifer. This means that the processes that occur are more complex, since the aquifer is separated from the seawater by the semiconfining layer which, under natural conditions, limits seawater intrusion (de Montety et al. 2008). In order to recognise the hydrogeochemical processes occurring in the interior of a coastal aquifer subject to abstractions, 30 surveys were done of the 3 boreholes, at weekly to fortnightly intervals over a period of 14 months. Over this period, P-b was pumped without interruption, at an initial rate of $23 \mathrm{~L} / \mathrm{s}$, and later, due to stability problems in the well, at a reduced rate of $12 \mathrm{~L} / \mathrm{s}$. In addition, seawater samples were taken just opposite the boreholes, and freshwater samples were taken from a borehole $670 \mathrm{~m}$ inland, also aligned with the other boreholes. Samples from the pumping well were taken at the head of the borehole. In the two observation wells, samples were taken using a small-diameter portable pump, pumping for $30 \mathrm{~min}$ before taking the sample to ensure that the sample was truly aquifer water and not standing water from inside the piezometer.

Temperature, electrical conductivity and $\mathrm{pH}$ were determined in situ. Alkalinity (as $\mathrm{HCO}_{3}{ }^{-}$) was determined by titration at the time of sampling. Samples were taken in duplicate, filtered using a $0.45-\mu \mathrm{m}$ Millipore filter and stored in polyethylene bottles at $4{ }^{\circ} \mathrm{C}$. For metals analysis, due to the problems of absorption or precipitation, the samples were acidified to $\mathrm{pH}<2$ with environmental grade (ultra pure) nitric acid. Sample composition was determined by means of ICP-Mass Spectrometer at the laboratory of the Spanish Geological Survey (IGME). Environmental water 


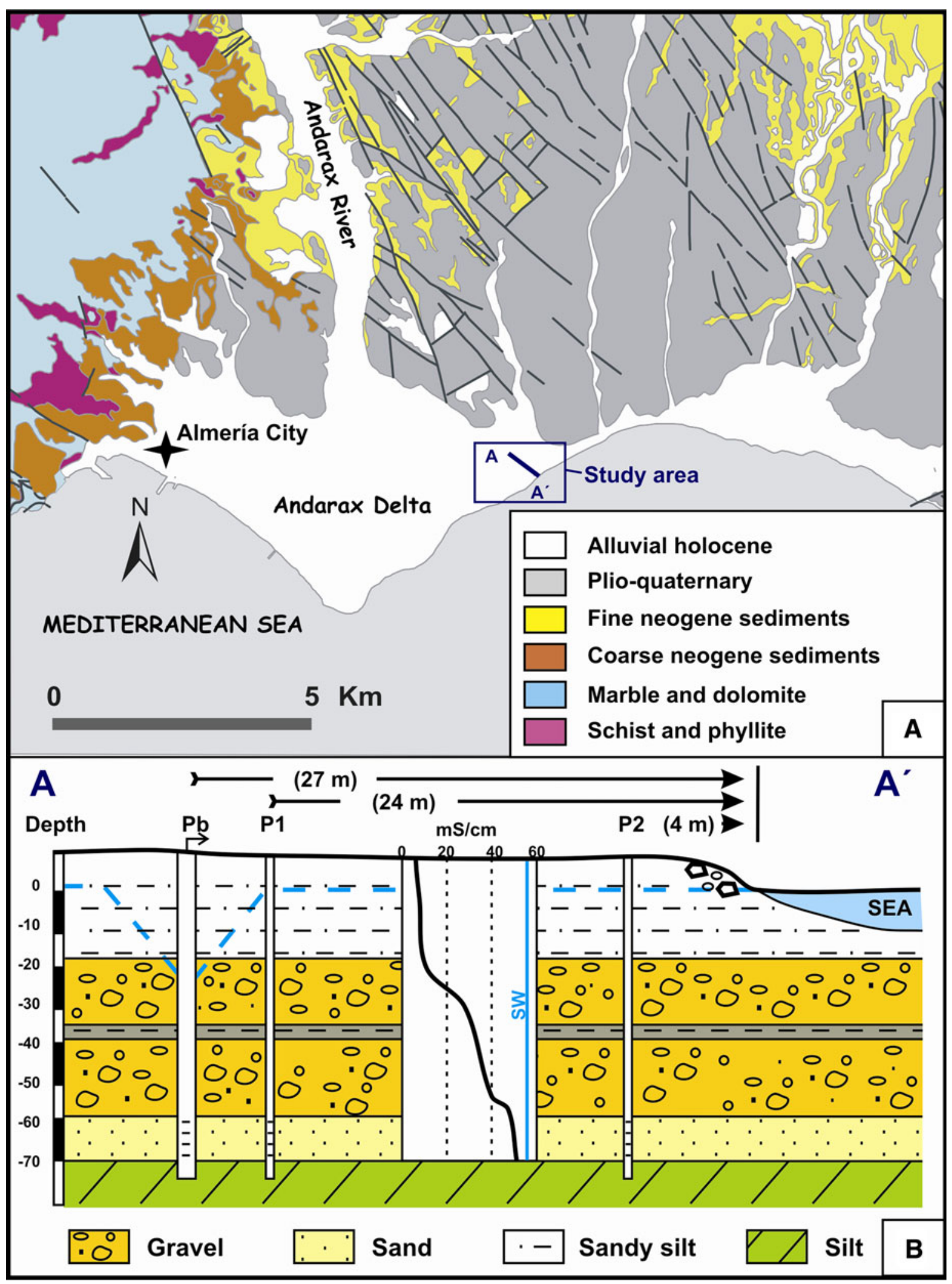

Fig. 1 a Hydrogeological map of the Lower Andarax. b hydrogeological scheme of the experimental monitoring system. The central graph shows the evolution of salinity $(\mathrm{mS} / \mathrm{cm})$ with depth. See location; $(P-b$ pumping well, $P-1$ piezometer $1, P-2$ piezometer $2, S W$ seawater) 
isotopes (oxygen 18 and deuterium) were also measured. These analyses were conducted at the Laboratory of Stable Isotopes in the Interdepartmental Research Service (SIdI), at the Autonomous University of Madrid. Isotope ratios were measured using an IRMS (Isotope Ratio Mass Spectrometer). Standards used are the Vienna Standard Mean Ocean Water (VSMOW). Analytical uncertainties are \pm 0.2 for $\delta^{18} \mathrm{O}$, and \pm 0.1 for $\delta^{2} \mathrm{H}$. Analyses of organic matter in the sediments were also done, through titration using ferrous ammonium sulphate, at the laboratory of the Spanish Geological Survey (IGME).

The ionic deltas were calculated $(\Delta)$ for the other major ions based on the theoretical percentage of seawater, deduced from the concentration of the chloride ion. The value of $\Delta$ ion is obtained as the difference between the measured concentration in the sample analysed and the theoretical value deduced from ideal mixing between seawater and freshwater (Fidelibus et al. 1993; PulidoLeboeuf 2004).

$[Y]_{\mathrm{T}}=[Y]_{\mathrm{sw}} x+[Y]_{\mathrm{fw}}(1-x)$,

where $[Y]_{\mathrm{T}}$ is the theoretical concentration of an ion, $[Y]_{\mathrm{sw}}$ is the concentration of ion in seawater, $[Y]_{\mathrm{fw}}$ : is the concentration of ion in freshwater and $x$ : is \% seawater calculated.

In this way, $\Delta Y$ is calculated as: $\Delta Y=[Y]_{\mathrm{R}}-[Y]_{\mathrm{T}}$ where, $[Y]_{\mathrm{R}}$ is the actual value measured in the sample. The calculated ionic deltas will show how near or far the ion concentration is from the theoretical value calculated for an ideal mixture. Positive ionic deltas indicate that there has been an enrichment as a result of modifying process, such as dissolution or ion exchange; values close to zero show that the ion has been subject to conservative mixing.

The mineral saturation indices (SI) indicate the degree of saturation in a particular mineral phase compared to the aqueous solution with which it is contact. Based on this SI value, the trend of precipitation or dilution of the mineral phases can be deduced. The SI was obtained using the PHREEQC code (Parkhurst and Appelo 1999). Accordant with the characteristics of the study plot, the phases analysed were: calcite, dolomite, gypsum and halite. The values were projected against the percentage of seawater calculated for each sample, and the line representing the theoretical SI for this percentage mix freshwater-seawater was added.

The isotope composition of each of the sampling points was analysed and its progression over time examined. Results, expressed as isotopic deviation $\delta(\%)$, were:

$\delta(\%)=\frac{\left(R_{\text {sample }}-R_{\text {vsmow }}\right)}{R_{\mathrm{vsmow}}} \times 10^{3}$,

where $R_{\text {sample }}$ is the isotopic ratio of the sample $\left({ }^{2} \mathrm{H} /{ }^{1} \mathrm{H}\right.$, ${ }^{18} \mathrm{O} /{ }^{16} \mathrm{O}$ ), and $R_{\mathrm{vsmow}}$ the isotope ratio of the international reference standard. The Pearson product-moment correlation coefficient was used to obtain the correlation between ${ }^{18} \mathrm{O}$ and ${ }^{2} \mathrm{H}$.

\section{Results and discussion}

Physico-chemical characteristics

Electrical conductivity (EC) exhibits a variable temporal evolution in the three boreholes. In the pumping well, it remained between 40 and $45 \mathrm{mS} / \mathrm{cm}$ (Fig. 2). Piezometer $\mathrm{P}-2$ underwent a clear increase in salinity, rising from 42 to $47 \mathrm{mS} / \mathrm{cm}$ over the first few months of the experiment. However, after reducing the pumping rate, the salinity decreased back close to initial values. In the piezometer closest to the pumping well (P-1) a drop in salinity was observed over the first few months of pumping, recovering once the pumping rate was reduced in P-b (Fig. 2). The three monitoring points exhibit values less than mean seawater $(54-57 \mathrm{mS} / \mathrm{cm})$, the most elevated values being recorded in the piezometer closest to the shore, which was the only borehole to show a clear increase in salinity as an effect of the pumping.

Before the start of continuous pumping, samples were taken to determine the physico-chemical characteristics of the waters under a natural regime and so that comparisons could be made with the influenced regime.

The geochemical data of groundwater (Table 1) were plotted on a triangular Piper diagram. Samples taken before and during the pumping had a sodium chloride facies very close to that of seawater (SW). However, samples of freshwater taken some $700 \mathrm{~m}$ from the coast $(\mathrm{FW})$ were calcium sulphate type (Fig. 3).

Because $\mathrm{Cl}^{-}$is considered the most conservative element in groundwater, its concentration is plotted against

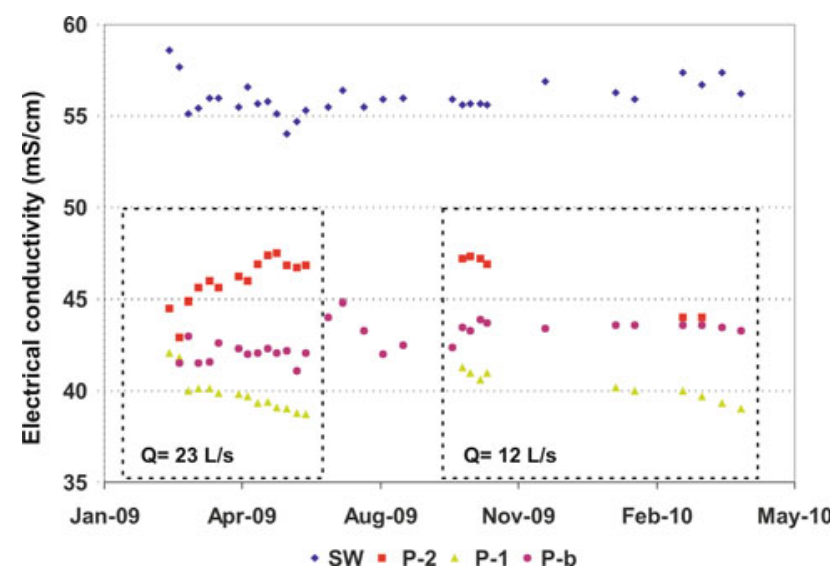

Fig. 2 Evolution of electrical conductivity in seawater (SW) and groundwater in P-b, P-1 and P-2 during the period of the experiment (EC in $\mathrm{mS} / \mathrm{cm} ; Q$ discharge in $\mathrm{L} / \mathrm{s}$ ) 


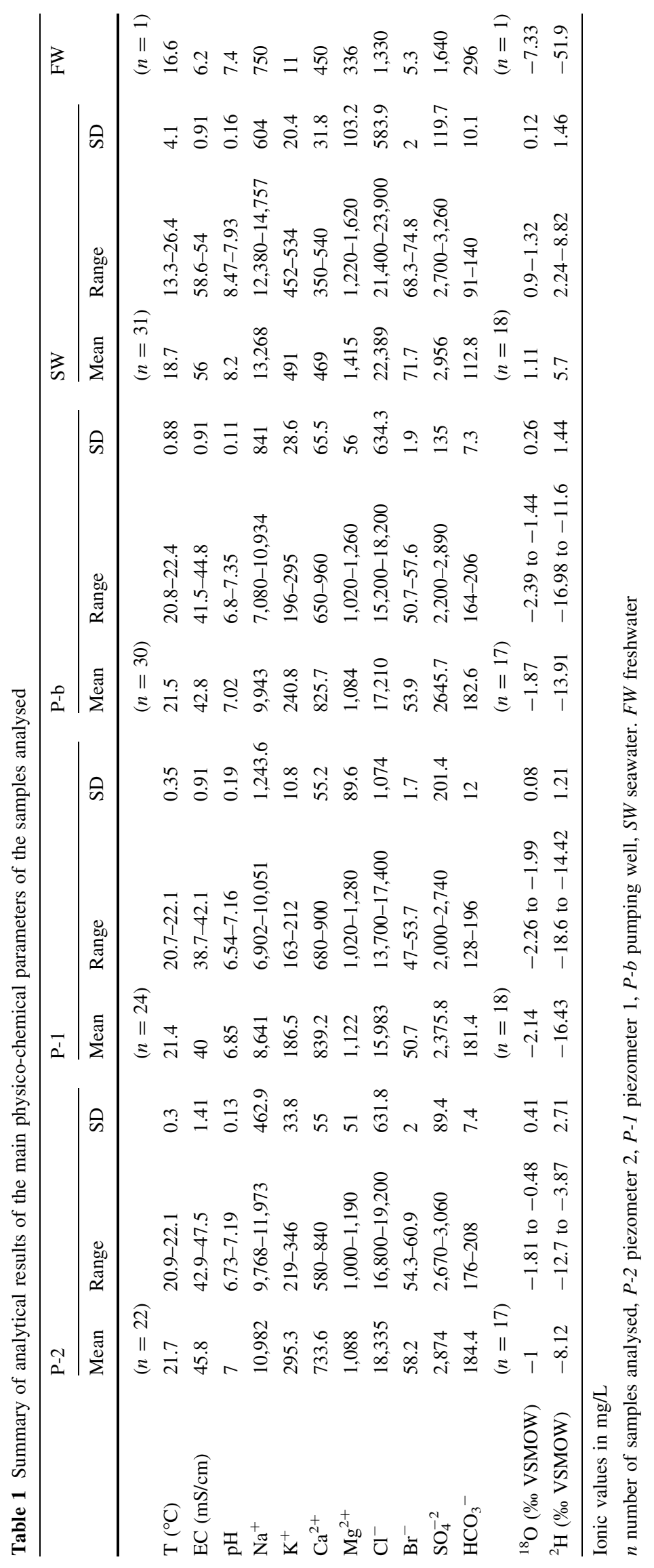


Fig. 3 Piper diagram (groundwater and seawater samples)

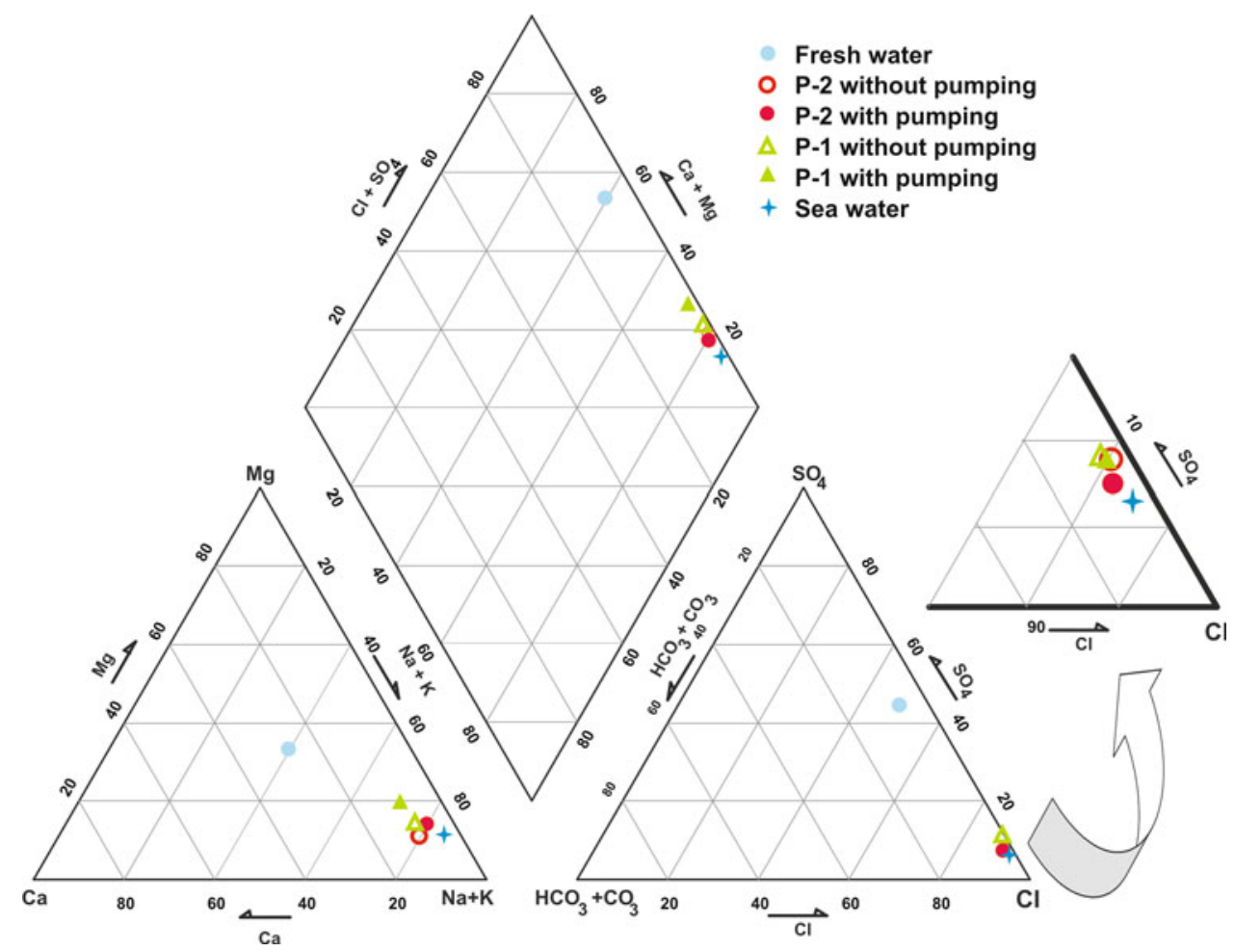

the concentration of other ions in the groundwater samples, and compared with the seawater-freshwater mixing line. $\mathrm{Na}^{+}$and $\mathrm{Br}^{-}$, both ions of marine origin, are closely aligned to the FW-SW line $\left(r^{2}=0,89\right) \cdot \mathrm{Ca}^{2+}, \mathrm{SO}_{4}{ }^{2-}$ and $\mathrm{K}^{+}$lie away from this straight line and sometimes had a different slope (Fig. 4). The molar $\mathrm{Br} / \mathrm{Cl}$ ratio, an indicator of the origin salinity in groundwaters (de Montety et al. 2008), lies close to 0.0015 for seawater and coastal aquifers in the Mediterranean region (Vengosh et al. 1999). The Br/ $\mathrm{Cl}$ ratios measured in samples varied between 0.0013 and $0.0016 ; 0.0014$ was the value obtained for seawater, and 0.0018 for the freshwater (Fig. 4). The majority of samples taken in the boreholes exhibited values close to seawater, indicating a high percentage of seawater in the mixture. Nevertheless, samples from piezometer P-1 gave slightly lower values, in-keeping with the records of EC (Fig. 4).

Quantification of seawater intrusion

The percentage of seawater in the samples was calculated from the chloride ion, according to the expression:

$x=\frac{\left(C_{\mathrm{Cl}, \text { sample }}-C_{\mathrm{Cl}, \mathrm{f}}\right)}{\left(C_{\mathrm{Cl}, \text { sea }}-C_{\mathrm{Cl}, \mathrm{f}}\right)} \times 100$,

where $\mathrm{Cl}^{-}$concentration is given by $C_{\mathrm{Cl} \text {,sample }}$, freshwater $\mathrm{Cl}^{-}$concentration is $C_{\mathrm{Cl}, \mathrm{f}}$ and seawater $\mathrm{Cl}^{-}$concentration, $C_{\mathrm{Cl} \text {,sea }}$. The results are presented in Table 2 . They indicate water containing between 56 and $88 \%$ of seawater, highest in $\mathrm{P}-2$ and lowest in $\mathrm{P}-1$. The trend in the percentage of seawater is similar to the values of EC; thus P-2 showed a gradual increase over the first few months of the experiment, before the percentage of seawater in the mixture fell again when the abstraction rate was reduced. Meanwhile, in $\mathrm{P}-1$, there was a successive reduction in the percentage of seawater at the higher pumping rate, an increase when the pumping rate was changed, followed by a gradual fall at the pumping rate of $12 \mathrm{~L} / \mathrm{s}$. The percentage of seawater in samples from the pumping well showed a slight increasing trend, but always remained in the range $70-80 \%$ of seawater.

Deviations of ion ratios

The results (Table 2) show certain variability, particularly for $\mathrm{Na}^{+}, \mathrm{Ca}^{+2}, \mathrm{Mg}^{+2}$ and $\mathrm{SO}_{4}^{-2}$ (Fig. 5). The $\Delta \mathrm{Ca}^{+2}$ is enriched by between 10 and $20 \mathrm{meq} / \mathrm{L}$ in the three test boreholes, showing a slight decreasing trend over time. $\Delta \mathrm{Mg}^{+2}$ is clearly impoverished during the first part of the experiment $\mathrm{P}-2$. In $\mathrm{P}-\mathrm{b}$ and $\mathrm{P}-1, \Delta \mathrm{Mg}^{+2}$ values are highly variable, but there is an increasing trend over time. The behaviour of the $\mathrm{Na}^{+}$ion is clearly inverse to the magnesium ion. The $\Delta \mathrm{SO}_{4}^{-2}$ for $\mathrm{P}-2$ takes positive values of between 3 and $7 \mathrm{meq} / \mathrm{L}$, in P-1 it is negative, and in P-b it is between 10 and $-10 \mathrm{meq} / \mathrm{L}$. The $\mathrm{K}^{+}$and $\mathrm{HCO}_{3}{ }^{-}$deltas remain stable throughout the experiment, with values of between -1 and -4 meq/L. 

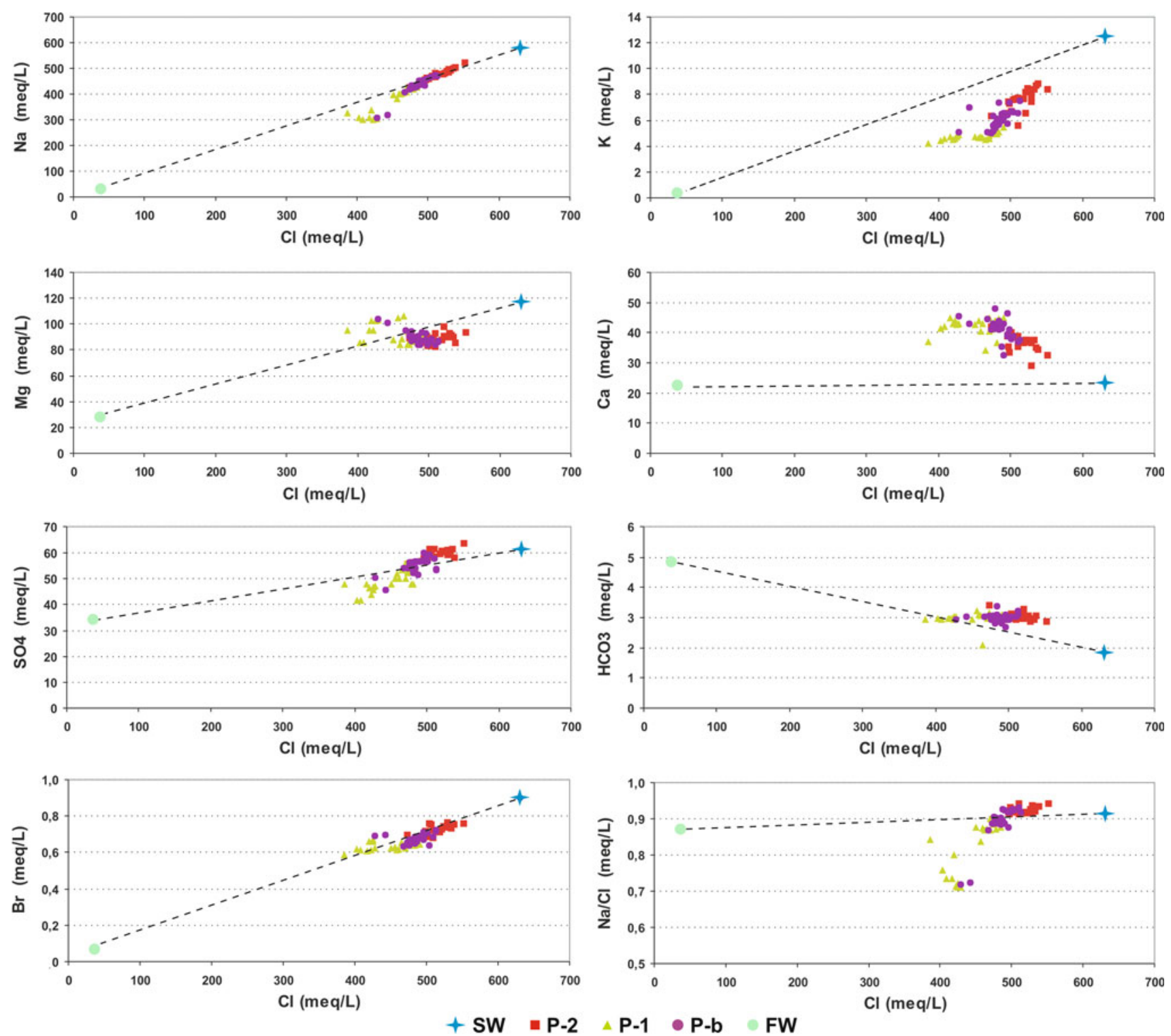

Fig. 4 Relationship between concentrations of major ions and conservative ion $\mathrm{Cl}$ (data in meq/L). The theoretical mixing line of freshwater (FW)-seawater (SW) is included

\section{Water-rock interaction}

Calcite is stable with the aqueous medium, although the SIs are slightly lower than the expected concentration for conservative mixing FW-SW. Dolomite SI also are below the conservative mixing line. However, this mineral phase can be precipitated since its SIs are slightly positive (Fig. 6), not the calcite, whose values are close to zero. The gypsum shows the opposite situation: the theoretical line is below that of the test samples, which means that there must be an additional source of these ions, on top of the $\mathrm{SO}_{4}^{-2}$ and $\mathrm{Ca}^{+2}$ incorporated by the mixing of freshwater and seawater. Even so, the SI of the samples is negative, which indicates that this phase could be actively dissolving. In the case of halite, there is a close correlation between the theoretical and measured values. This phase is clearly subsaturated in the aqueous medium and its main origin is seawater.

Stable isotope analyses

In coastal aquifers, the ${ }^{18} \mathrm{O} /{ }^{2} \mathrm{H}$ ratio can be used to identify the degree of mixing between freshwater and seawater. When there is simply dilution between the seawater and the continental water, samples with an intermediate salinity will fall on the line of theoretical mixing. Deviations away 
Table 2 Summary of ionic delta values $(\Delta)$, SI of main mineral phases and $\%$ seawater (SW) calculated from $\mathrm{Cl}$ ion and $\delta^{18} \mathrm{O}$, for each sampling point

\begin{tabular}{|c|c|c|c|c|c|c|c|c|c|}
\hline & \multicolumn{3}{|l|}{$\mathrm{P}-2$} & \multicolumn{3}{|l|}{ P-1 } & \multicolumn{3}{|l|}{ P-b } \\
\hline & Mean & Range & SD & Mean & Range & SD & Mean & Range & SD \\
\hline & $(n=22)$ & & & $(n=24)$ & & & $(n=30)$ & & \\
\hline$\Delta \mathrm{Na}^{+}$ & 6.88 & -18.1 to 22.3 & 11.96 & -35.8 & -82.8 to -6.7 & 26.4 & -11.3 & -85.3 to 5.6 & 20.2 \\
\hline$\Delta \mathrm{K}^{+}$ & -2.49 & -3.84 to -1.64 & 0.67 & -3.9 & -4.8 to -2.6 & 0.57 & -3.3 & -4.6 to -1.6 & 0.69 \\
\hline$\Delta \mathrm{Ca}^{+2}$ & 11.2 & 7.45 to 15.32 & 1.88 & 15.5 & 7.3 to 20.1 & 3 & 15.3 & 10.9 to 21.7 & 2.8 \\
\hline$\Delta \mathrm{Mg}^{+2}$ & -11.9 & -24.4 to 12.3 & 10.4 & 0.81 & -11 to 25.6 & 10.3 & -6.6 & -16.2 to 9.2 & 6.7 \\
\hline$\Delta \mathrm{SO}_{4}{ }^{-2}$ & 2.27 & -0.81 to 6.9 & 1.94 & -6.33 & -13.8 to 0.58 & 4.3 & -2.11 & -12.5 to 2.3 & 3.2 \\
\hline$\Delta \mathrm{HCO}_{3}{ }^{-}$ & -0.14 & -0.47 to 0.48 & 0.23 & -0.95 & -1.56 to -0.5 & 0.34 & -0.5 & -1.25 to -0.2 & 0.23 \\
\hline $\mathrm{SI}_{\mathrm{cal}}$ & -0.01 & -0.25 to 0.19 & 0.13 & -0.07 & -0.87 to 0.18 & 0.23 & 0.07 & -0.15 to 0.46 & 0.11 \\
\hline $\mathrm{SI}_{\mathrm{dol}}$ & 0.5 & 0.03 to 0.85 & 0.25 & 0.34 & -1.2 to 0.89 & 0.47 & 0.61 & 0.15 to 1.42 & 0.23 \\
\hline $\mathrm{SI}_{\text {gyp }}$ & -0.3 & -0.44 to -0.3 & 0.03 & -0.33 & -0.41 to -0.26 & 0.04 & -0.31 & -0.4 to -0.24 & 0.03 \\
\hline $\mathrm{SI}_{\text {hal }}$ & $\begin{array}{l}-2.5 \\
(n=17)\end{array}$ & -2.6 to -2.44 & 0.03 & $\begin{array}{l}-2.67 \\
(n=18)\end{array}$ & -2.8 to -2.6 & 0.09 & $\begin{array}{l}-2.58 \\
(n=17)\end{array}$ & -2.78 to -2.52 & 0.06 \\
\hline$\% \mathrm{SW}(\mathrm{Cl})$ & 80 & $74-88$ & 3.8 & 68 & $61-74$ & 4.5 & 74 & $65-78$ & 3 \\
\hline$\% \mathrm{SW}\left({ }^{18} \mathrm{O}\right)$ & 75 & $67-81$ & 4.6 & 62 & $60-63$ & 1.1 & 66 & $60-70$ & 2.9 \\
\hline
\end{tabular}

$\Delta$ values in $\mathrm{meq} / \mathrm{L}$

$n$ number of samples analysed, $P-2$ piezometer $2, P-1$ piezometer $1, P-b$ pumping well
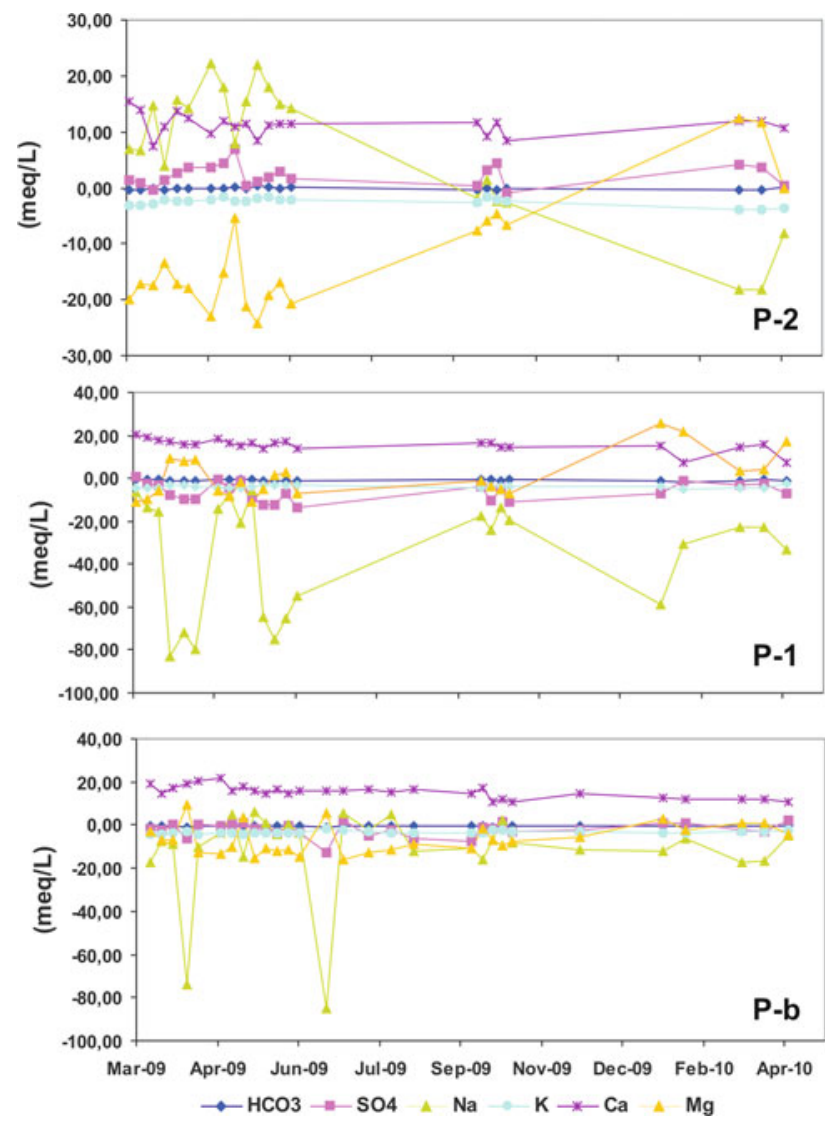

Fig. 5 Evolution of ionic $\Delta$ during the period of pumping (in meq/L) from this line can occur if mixing incorporates waters from different aquifers, with an area of recharge situated at a different elevation (Schiavo et al. 2009).

Our samples show values oscillating between 1.3 and $-7.3 \%$ in $\delta^{18} \mathrm{O}$ and between 7 and $-52 \%$ in $\delta^{2} \mathrm{H}$. The most impoverished isotopic samples correspond to the freshwater taken $700 \mathrm{~m}$ from the coastline. The remaining samples exhibit milder impoverishment, as a function of their percentage seawater content. All samples fall along the line of theoretical mixing, indicating the conservative character of these isotopes (Fig. 7). The seawater samples and P-1 are more closely grouped than those from the pumping well and P-2. In these two boreholes, the samples are aligned along the theoretical mixing line, showing the variation of salinity that these aquifer horizons have undergone through time. The degree of correlation between the two isotopes for the samples as a whole, is high $\left(r^{2}=0.98\right)$. The isotope values of the freshwater are close to those expected for GMWL. However, the seawater is enriched in $\delta^{18} \mathrm{O}$, whilst the proportion of $\delta^{2} \mathrm{H}$ with respect to the GMWL is maintained. The reason that the seawater is enriched in $\delta^{18} \mathrm{O}$ must be due to evaporation on the surface of the sea under non-equilibrium conditions (Gonfiantini and Araguás 1988; Carol et al. 2009).

The conservative character of the environmental isotopes allows the percentage of seawater to be calculated based on the ${ }^{18} \mathrm{O}$ content, in a similar fashion to the $\mathrm{Cl}$ ion. 

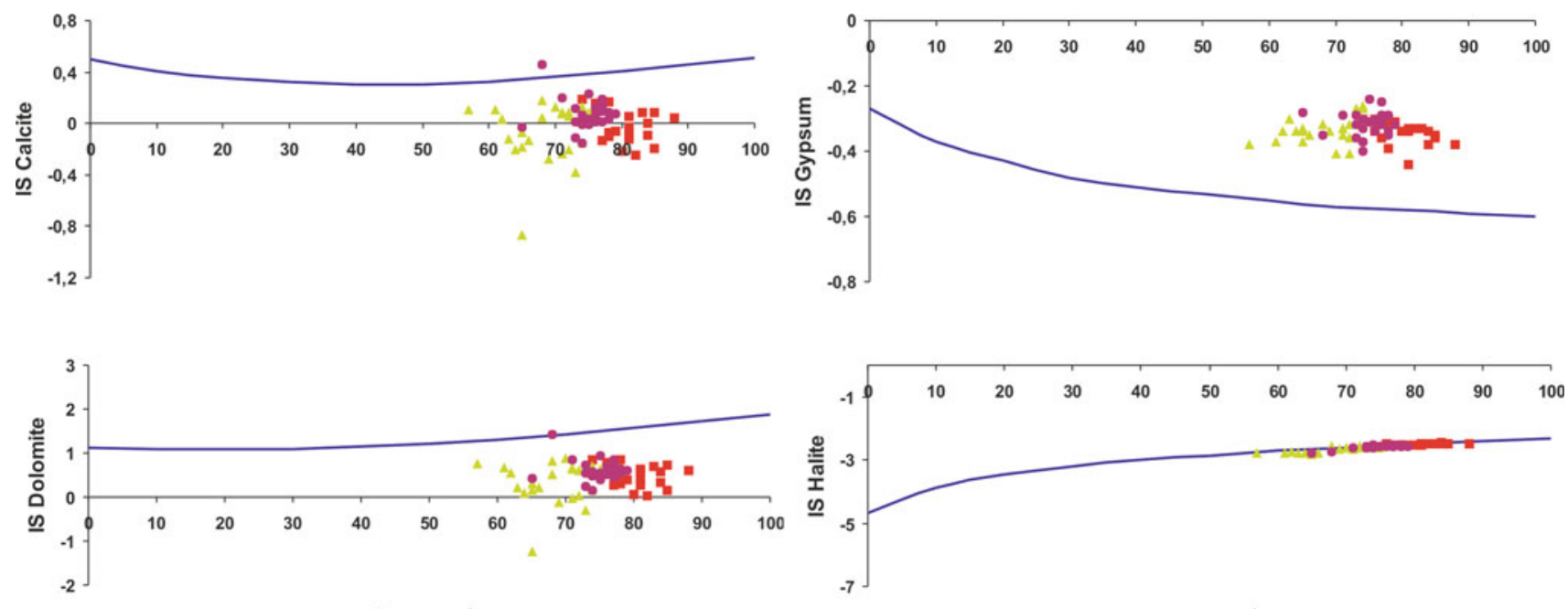

$\%$ seawater

- P-2

$\triangle \mathrm{P}-1 \quad \mathrm{P}-\mathrm{b}$

$\%$ seawater

Fig. 6 Saturation indexes of calcite, dolomite, gypsum and halite in sampled water versus percentage of seawater. Theoretical SI values for a conservative mixture have been included (solid line)

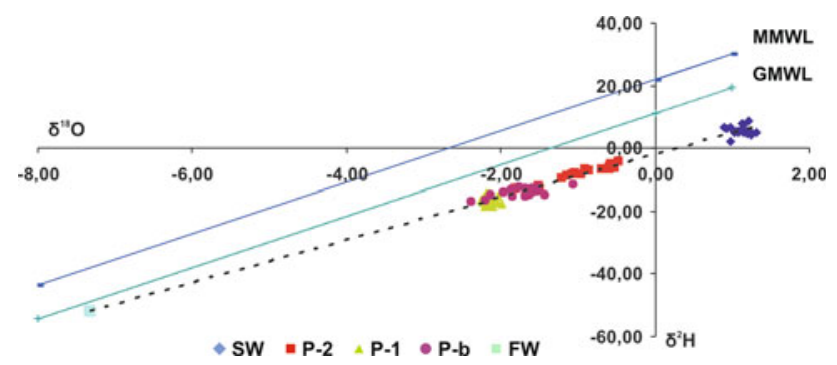

Fig. $7 \delta^{2} \mathrm{H} / \delta^{18} \mathrm{O}$ relationship for samples from the Lower Andarax aquifer (data in \%o). GMWL global meteoric water line, $M M W L$ Mediterranean meteoric water line

The results obtained are parallel to those for $\mathrm{Cl}$, albeit 5-10\% lower (Fig. 8).

Dissolution and reduction of sulphates

Marine intrusion processes are usually accompanied by a reduction in the concentration of sulphates compared to conservative mixing (Magaritz and Luzier 1985; Cai et al. 2003; Andersen et al. 2005). This deficit is usually linked to bacterial reduction processes (Bosch and Custodio 1993; Martinez and Bocanegra 2002; Yamanaka and Kumagai 2006), according to the reaction: $2 \mathrm{CH}_{2} \mathrm{O}+\mathrm{SO}_{4}^{-2} \rightarrow$ $2 \mathrm{HCO}_{3}{ }^{-}+\mathrm{H}_{2} \mathrm{~S}$. However, in order that this reaction takes place, certain conditions are required in the medium, whose assumed existence is not always warranted, such as a high concentration of organic matter and anoxic conditions (Appelo and Postma 2005). Whilst the boreholes were being constructed, samples taken at 60-70 m depth corresponded to sediments. These samples contained between 50 and $300 \mathrm{mmol} \mathrm{C} / \mathrm{Kg}$ and their measured Eh ranged from 50 to
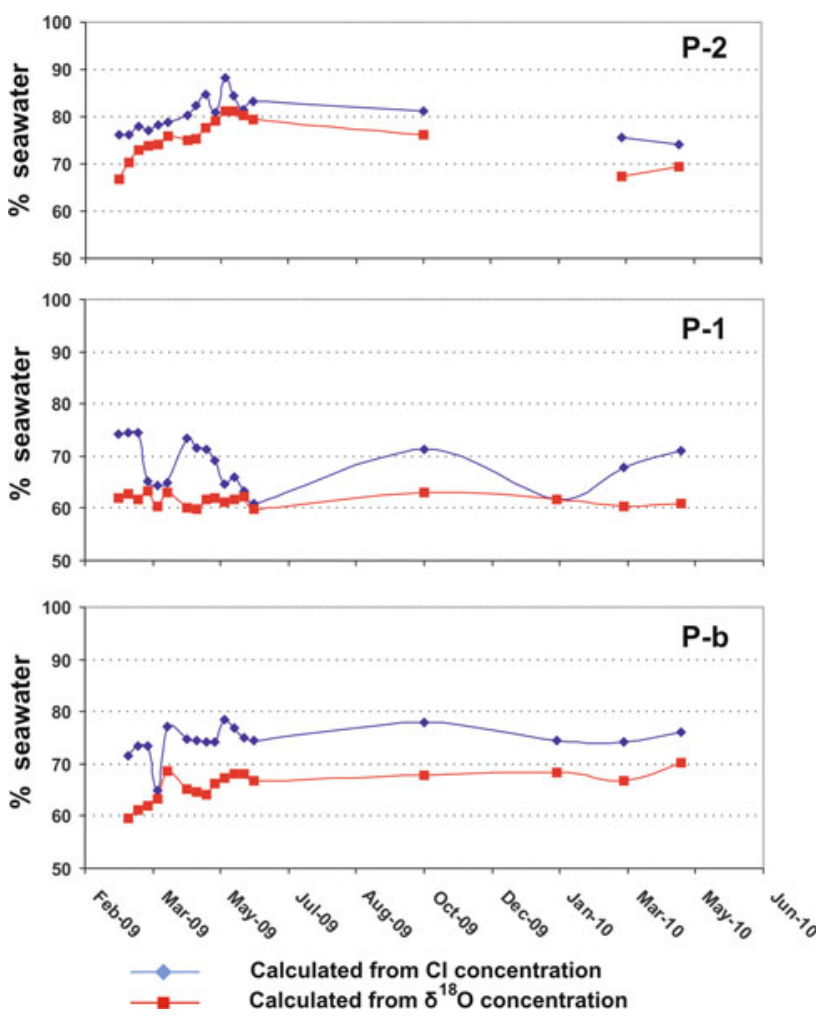

Fig. 8 Comparison of the percentage of seawater in samples calculated from the $\mathrm{Cl}$ ion and $\delta^{18} \mathrm{O}$

$150 \mathrm{mV}$, values far from those suitable for sulphate reduction. Because of this inconsistency, other authors have related the deficit of ion sulphate compared to conservative mixing to precipitation of gypsum at the intrusion front. 
This process would create the deficit inland, where the percentage of mixing is below $50 \%$ (Gomis-Yagües et al. 2000).

The cation exchange reactions that take place at the intrusion front liberate the $\mathrm{Ca}$ ion, and so favour saturation in gypsum. In the study area, there is a pattern of excess sulphate in samples taken from close to the coastline (P-2), with a deficit inland (P-1). All samples analysed, with percentages of seawater between 60 and $90 \%$, give negative SIs for gypsum, so precipitation of this mineral phases is ruled out. The values of SI above that expected (Fig. 6) could be related to gypsum dissolution (PulidoLeboeuf 2004; el Yaouti et al. 2009). At the base of the aquifer there are secondary gypsums intercalated between the silts, and it could be these that cause the excess $\mathrm{SO}_{4}$ ion recorded in piezometer $\mathrm{P}-2$. In $\mathrm{P}-1, \Delta \mathrm{SO}_{4}^{-2}$ values begin positive, but become negative when pumping starts in $\mathrm{P}-\mathrm{b}$. This impoverishment in the $\mathrm{SO}_{4}$ ion compared to conservative mixing could be linked to fixation of the sulphate ion as a result of precipitation of mineral phases associated with the generation of a biofilm around the pumping well (Cullimore 2008). Piezometer P-1, situated only $4 \mathrm{~m}$ from $\mathrm{P}-\mathrm{b}$ falls under the influence of P-b, and it could be that local sulphate reduction was occurring. Samples of mineral grains extracted from the aquifer formation once pumping began, were analysed using SEM coupled with EDX, and this indicated the presence of sulphides and/or sulphates as neoformed mineral phases.

\section{Dolomitization}

The SI of the carbonate minerals lies close to the line of equilibrium, with values below that for the theoretical freshwater-seawater mixing (Fig. 6). This could be linked to precipitation of one or more of the phases. The ideal conditions for dolomitization occur when the calcite SI is negative and the dolomite SI is positive (Pulido-Leboeuf 2004). According to Magaritz et al. (1980), a basic requirement for deposition of dolomite is that the $\mathrm{Mg}^{2+} / \mathrm{Ca}^{2+}$ ratio is greater than 1 . This condition is met in all the samples analysed (Table 1), whilst the calcite SI is negative in samples taken during the first few months of sampling, when marine intrusion was more clearly produced. Thus, it is highly likely that dolomitization occurred in the aquifer during the experiment. The precipitation of dolomite would explain the slightly negative ionic deltas (between -0.2 and $-3 \mathrm{meq} / \mathrm{L}$ ) of the ion $\mathrm{HCO}_{3}$ and SI below the expected for carbonate phases (Fig. 6).

Ion exchange reactions

The variations observed in $\Delta \mathrm{Na}$ and $\Delta \mathrm{Mg}$ have a clear inverse relationship (Fig. 5). Nevertheless, the absolute values do not cancel each other out, indicating that there must be another ion that could intervene in this relationship (Capaccioni et al. 2005). The $\Delta \mathrm{Ca}$ values of all samples are above the expected value, and no great variations are seen over time. Given that $\mathrm{Ca}^{2+}$ can play a similar role to $\mathrm{Mg}^{2+}$, we incorporate the $\Delta \mathrm{Mg}$, and in this way the $\Delta \mathrm{Na}-\Delta \mathrm{Ca}+\mathrm{Mg}$ relationship fits fairly closely to a $1: 1$ straight line (Fig. 9). The samples that best fit this straight line are those taken in P-b (Fig. 9), whilst some from P-2 are placed slightly above the line, probably due to an excess of $\mathrm{Ca}^{2+}$ from gypsum dissolution. The $1: 1 \Delta \mathrm{Na}-\Delta \mathrm{Ca}+\mathrm{Mg}$ ratio can be attributed to cation exchange. Throughout the experiment, a process of exchange was deduced, whereby $\mathrm{Ca}^{2+}$ is liberated and $\mathrm{Na}^{+}$is fixed (Fig. 5). This reaction of reverse ion exchange is typical of marine intrusion processes. Simultaneously, another process is recognised involving $\mathrm{Na}^{+}$and $\mathrm{Mg}^{2+}$. In this case, it is observed that over the course of the experiment, there were moments when the process of fixation and liberation of these ions was reversed (Fig. 5), probably determined by the degree of intrusion (advance or recession of the saline wedge) and/ or by the recharge produced during rainy periods; the $\mathrm{Mg}^{2+}$ would be more sensitive to small variations in water salinity, whilst $\mathrm{Ca}^{2+}$ behaves in a more consistent way through the pumping test.

There is a high cation exchange capacity (CEC) in the aquifer horizon from which the samples were taken, because of the elevated concentration of clay-sized grains (reaching nearly $10 \%$ ), and concomitant organic carbon content of $0.2 \%$. Applying these values in the empiric equation of Breeuwsma et al. (1986), the CEC of the groundwater is $500 \mathrm{meq} / \mathrm{L}$. Knowing the capacity for cation exchange of the substratum, one should find out the cation exchange capacity of each of the ions and see if the CEC of the substratum is capable to satisfy this capacity of exchange. These calculations use the parameter equivalent fraction of exchange for the major ions $\left(\beta_{\mathrm{I}}\right)$, and an additional parameter $\left(\mathrm{K}_{\mathrm{Na} / \mathrm{I}}\right)$ to indicate the exchange coefficient of each cation with respect to $\mathrm{Na}^{+}$. The major elements involved in the exchange process are: $\mathrm{Na}^{+}, \mathrm{K}^{-}, \mathrm{Ca}^{2+}, \mathrm{Mg}^{2+}$.

According to Appelo and Postma (2005):

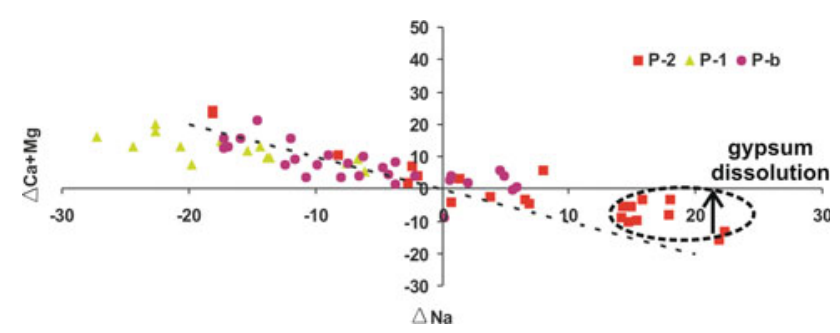

Fig. $9 \Delta \mathrm{Na}$ versus $\Delta \mathrm{Ca}+\mathrm{Mg}$ for each sample (in meq/L). The broken line shows the 1:1 ratio 
$\beta_{\mathrm{Na}}+\beta_{\mathrm{Ca}}+\beta_{\mathrm{Mg}}+\beta_{\mathrm{K}}=1$

$\beta_{\mathrm{Na}}^{2}\left(\frac{\left[\mathrm{Mg}^{2+}\right]}{\mathrm{K}_{\mathrm{Na} / \mathrm{Mg}}^{2}\left[\mathrm{Na}^{+}\right]^{2}}+\frac{\left[\mathrm{Ca}^{2+}\right]}{\mathrm{K}_{\mathrm{Na} / \mathrm{Ca}}^{2}\left[\mathrm{Na}^{+}\right]^{2}}\right)+\frac{\beta_{\mathrm{Na}}\left[\mathrm{K}^{+}\right]}{K_{\mathrm{Na} / \mathrm{K}}\left[\mathrm{Na}^{+}\right]}$

$$
+\beta_{\mathrm{Na}}-1=0
$$

$\beta_{\mathrm{Mg}}=\frac{\beta_{\mathrm{Na}}^{2}\left[\mathrm{Mg}^{2+}\right]}{\mathrm{K}_{\mathrm{Na} / \mathrm{Mg}}^{2}\left[\mathrm{Na}^{2+}\right]^{2}} ; \quad \beta_{\mathrm{Ca}}=\frac{\beta_{\mathrm{Na}}^{2}\left[\mathrm{Ca}^{2+}\right]}{\mathrm{K}_{\mathrm{Na} / \mathrm{Ca}}^{2}\left[\mathrm{Na}^{2+}\right]^{2}} ;$

$\beta_{\mathrm{K}}=\frac{\beta_{\mathrm{Na}}\left[\mathrm{K}^{+}\right]}{\mathrm{K}_{\mathrm{Na} / \mathrm{K}}\left[\mathrm{Na}^{2+}\right]}$, where:

$\mathrm{K}_{\mathrm{Na} / \mathrm{Mg}}=0.5 ; \quad \mathrm{K}_{\mathrm{Na} / \mathrm{Ca}}=0.4 ; \quad \mathrm{K}_{\mathrm{Na} / \mathrm{K}}=0.2$.

Solving these equations gives the values of $\beta_{\mathrm{I}}$ in Table 3 . Figure 10a shows the distribution (from the sea moving inland) of the mean $\beta_{\mathrm{I}}$ obtained. Data from P-b are not included because of the distorting effect produced by vertical pumping from the borehole, which caused upconing, which means that samples taken from this point have a higher salinity than at points closer to the coast (Fig. 2). From the shoreline moving inland, the exchange

Table 3 Equivalent fraction of exchange $(\beta)$ and potential exchange $(\Delta \beta)$ for cations (in meq/L) between seawater (SW) and freshwater (FW)

\begin{tabular}{lllllllrrr}
\hline & SW & P-2 & P-1 & P-b & FW & & SW-FW & $($ SW-FW $) \times$ CEC $(\mathrm{meq} / \mathrm{L})$ \\
\hline$\beta_{\mathrm{Na}}$ & 0.589 & 0.557 & 0.457 & 0.506 & 0.103 & $\Delta \beta_{\mathrm{Na}}$ & 0.487 & 243 \\
$\beta_{\mathrm{Mg}}$ & 0.263 & 0.241 & 0.296 & 0.269 & 0.376 & $\Delta \beta_{\mathrm{Mg}}$ & -0.113 & 57 \\
$\beta_{\mathrm{Ca}}$ & 0.082 & 0.157 & 0.215 & 0.198 & 0.514 & $\Delta \beta_{\mathrm{Ca}}$ & -0.432 & 216 \\
$\beta_{\mathrm{K}}$ & 0.066 & 0.046 & 0.030 & 0.035 & 0.033 & $\Delta \beta_{\mathrm{K}}$ & 0.033 & 17 & \\
\hline
\end{tabular}

$P$-2 piezometer $2, P-1$ piezometer $1, P-b$ pumping well, $C E C$ cation exchange capacity
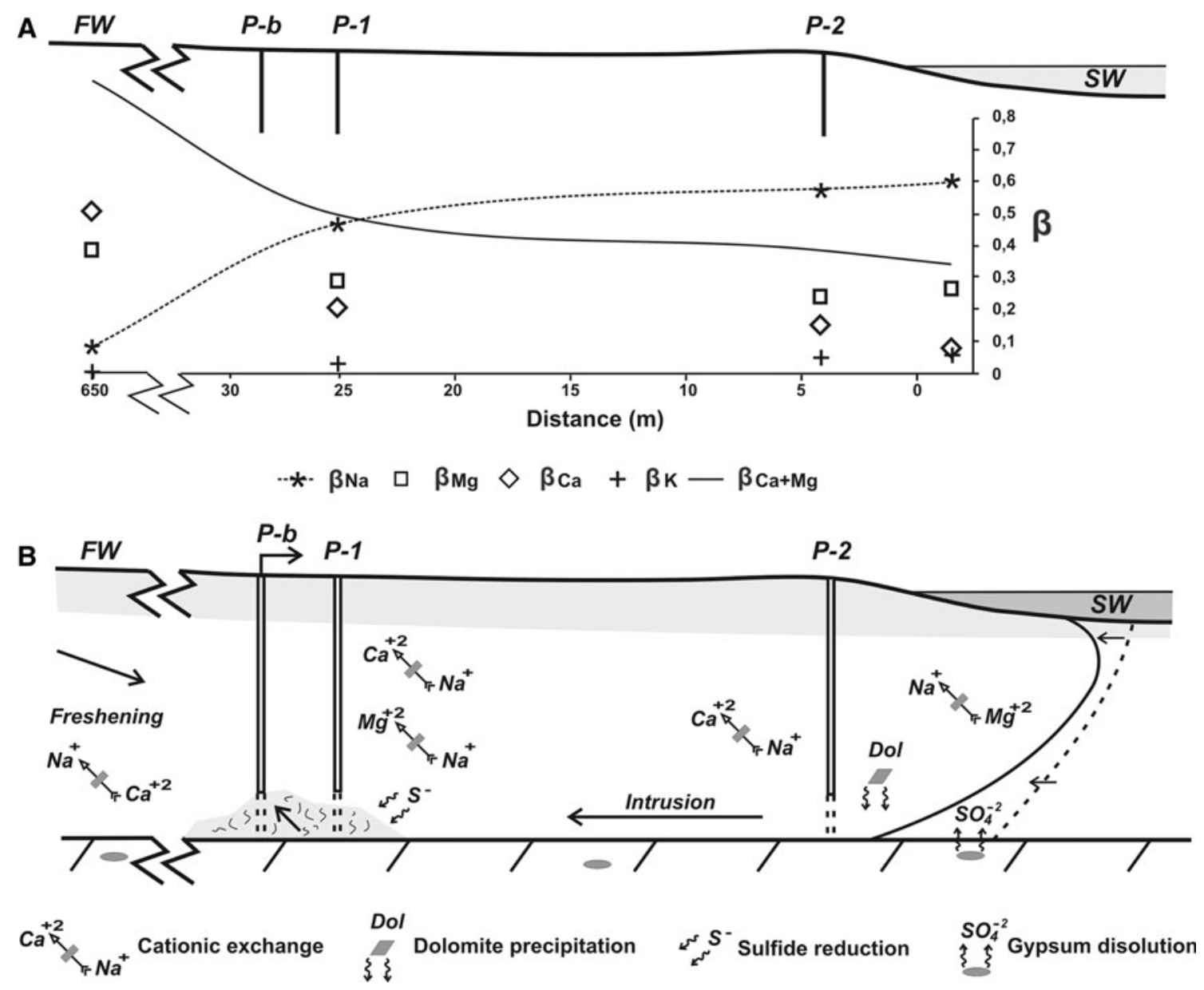

Fig. 10 a Distribution of mean $\beta_{\mathrm{I}}$ for the main cations through the studied aquifer horizon. b Scheme showing the main hydrogeochemical processes recognised in the study area 
capacity of $\mathrm{Ca}^{2+}$ and $\mathrm{Mg}^{2+}$ ions increases, $\mathrm{Mg}^{2+}$ having a greater capacity than $\mathrm{Ca}^{2+}$ in the two piezometers (Fig. 10a). This would explain why the magnesium ion is more sensitive to the small variations in salinity and why its time series fluctuates more. In turn, $\beta_{\mathrm{Na}}$ reduces rapidly and follows the inverse trajectory to the sum $\beta_{\mathrm{Ca}}+\mathrm{Mg}$ (Fig. 10a). The $\mathrm{K}^{+}$ion shows a lower fraction of cation exchange, falling slowly away from the coast. The record of $\beta_{\mathrm{I}}$ from $\mathrm{P}-\mathrm{b}$ moving inland shows a pattern of $\mathrm{Ca}>\mathrm{Mg}>\mathrm{Na}^{+}$, which is characteristic of a coastal aquifer subject to flushing (Andersen et al. 2005). From the coastline towards $\mathrm{P}-\mathrm{b}$, the $\mathrm{Na}^{+}>\mathrm{Mg}^{2+}>\mathrm{Ca}^{2+}$ sequence should show a process of seawater intrusion (Martinez and Bocanegra 2002), with sampling points P-b and P-1 lying in the zone where the $\beta_{\mathrm{Na} \text { and }} \beta_{\mathrm{Ca}}+\mathrm{Mg}$ trend lines intersect. As a result, the ion exchange between $\mathrm{Na}^{+}$ and $\mathrm{Mg}^{2+}$ at these points fluctuated over the period of sampling, depending on whether one or the other line is superimposed (Fig. 10a). An inversion was also recognised in $\mathrm{P}-2$, producing liberation of $\mathrm{Na}^{+}$and fixation of $\mathrm{Mg}^{2+}$ in the first part of the experiment, and vice versa in the second part (Fig. 5). In the initial stages the negative $\Delta \mathrm{Mg}$ could be linked to precipitation of dolomite. This precipitation causes an $\mathrm{Mg}^{2+}$ deficit in the water inside the aquifer that it could be compensate with the liberation of $\mathrm{Na}^{+}$. Therefore, there are two processes identified in P-2 in the first moments of the intrusion: precipitation of dolomite and, consequently, ion exchange. Figure 10b shows a scheme of the main modifying processes identified in the aquifer horizon studied.

The value of cation exchange of each ion species will be given by the difference in the value of $\beta_{\mathrm{I}}$ for the different water types along a flowline $\left(\Delta \beta_{\mathrm{I}}\right)$ (Sivan et al. 2005). Positive $\Delta \beta_{\mathrm{I}}$ values indicate impoverishment in the ion, whilst negative ones show enrichment due to flushing of the substrate (Table 3). The general trend of cation fractioning, which occurs between the seawater and freshwater horizons in the aquifer, shows $\Delta \beta_{\mathrm{I}}$ values that coincide with the trends observed for the ionic deltas calculated for the chloride ion. There is a trend of impoverishment in $\mathrm{Na}^{+}$ and $\mathrm{K}^{+}$and enrichment in $\mathrm{Mg}^{2+}$ and $\mathrm{Ca}^{2+}$ (Table 3). Multiplying the $\Delta \beta_{\mathrm{I}}$ by the CEC calculated (500 meq/L), it is obtained the capacity for cation exchange (in meq/L) for each chemical element. These values far surpass the ionic deltas calculated for the $\mathrm{Cl}^{-}$, which means that they can be explained by cation exchange.

\section{Conclusions}

A hydrogeochemical study was undertaken on the coastal band of a semi-confined coastal aquifer subjected to pumping. It enabled a whole series of processes to be identified close to the shore that are linked to the advance of the marine wedge. These processes modify the water chemistry away from expected values for conservative freshwater-seawater mixing. The main modifying process was cation exchange, with $\mathrm{Na}^{+}, \mathrm{Ca}^{2+}$ and $\mathrm{Mg}^{2+}$ are the ions most implicated. Throughout the coastal band studied cation exchange was produced, whereby $\mathrm{Na}^{+}$is fixed and $\mathrm{Ca}^{2+}$ is liberated. Concurrently, there was an exchange between $\mathrm{Na}^{+}$and $\mathrm{Mg}^{2+}$ ions. In this case, the $\mathrm{Mg}^{2+}$ showed a fluctuating behaviour, with fixation or liberation occurring depending on the degree of intrusion or recharge to the aquifer. In addition, at the intrusion front, gypsum dissolution and precipitation of dolomite were also identified. The effect of continuous pumping not only encouraged marine intrusion, but could also have propitiated generation of a biofilm where local conditions were suitable for reduction of sulphates to take place. Knowledge of how all these processes occur may prove to be important, given the uses to which these saline waters are intended, such as the provision the supply of water to desalination plants due to this water does not have consequences to human health. The media aquifer acts as an effective filter that reduces and/or removes the contents in bacteria, turbidity, organic matter etc., in the water.

Acknowledgments This work was undertaken within the framework of project 017/SGTB/2007/2.1. funded by the Spanish Ministry of the Environment and project CGL2007-63450/HID funded by the Spanish Ministry of Science. We also wish to express our gratitude to the members of OHL Medio Ambiente Inima and Spanish Geological Survey (IGME) that are collaborated in this project.

\section{References}

Abdalla O, Ali M, Al-Higgi K, Al-zidi H, El-Hussain I, Al-Hinai S (2010) Rol of sea water intrusion estimated by geophysical methods in an arid area: Al-Khabourah, Oman. Hydrogeol J 18:1437-1445. doi:10.1007/s10040-010-0606-0

Abd-Elhamid HF, Javadi AA (2011) A density-dependant finite element model for analysis of saltwater intrusion in coastal aquifers. J Hydrol 401:259-271. doi:10.1016/j.jhydrol.2011. 02.028

Andersen M, Nyvang V, Jakobsen R, Postma D (2005) Geochemical processes and solute transport at the seawater/freshwater interface of a sandy aquifer. Geochim Cosmochim Acta 69: 3979-3994. doi:10.1016/j.gca.2005.03.017

Appelo CAJ (1994) Cation and proton exchange, $\mathrm{pH}$ variations and carbonate reactions in a freshening aquifer. Water Resour Res 30:2793-2805. doi:10.1029/94WR01048

Appelo CAJ, Postma D (2005) Geochemistry, groundwater, and pollution, 2nd edn. AA Balkema, Rotterdam

Bear J, Chen D, Sorek S, Ouazar D, Herrera I (1999) Sea water intrusion in coastal aquifer: concepts, methods and practices. Kluwer Academic, Dordrecht

Beekman HE, Appelo CAJ (1990) Ion chromatography of fresh- and salt-water displacement: laboratory experiments and multicomponent transport modelling. J Contam Hydrol 7:21-37 
Boluda N, Gomis-Yagües V, Ruiz-Beviá F (2008) Influence of transport parameters and chemical properties of the sediment in experiments to measure reactive transport in seawater intrusion. J Hydrol 357:29-41. doi:10.1016/j.jhydrol.2008.04.021

Bosch X, Custodio E (1993) Dissolution processes in the freshwatersaltwater mixing zone in the Cala Jostel area (Vandellós, Tarragona). In: Proceedings of the XII salt water intrusion meeting, CIMNE-UPC. Barcelona, pp 229-244

Breeuwsma A, Wosten JH, Vleeshouwer JJ, Van Slobbe AM, Bouma J (1986) Derivation of land qualities to assess environmental problems from soil surveys. Soil Sci Soc Am J 50:186-190. doi: 10.2136/sssaj1986.03615995005000010035x

Cai WJ, Wang Y, Krest J, Moore WS (2003) The geochemistry of dissolved inorganic carbon in a surficial groundwater aquifer in North Inlet, South Carolina and the carbon fluxes to the coastal ocean. Geochim Cosmochim Acta 67:631-637. doi:10.1016/ S0016-7037(02)01167-5

Capaccioni B, Didero M, Paletta C, Didero L (2005) Saline intrusion and refreshening in a multilayer coastal aquifer in the Catania Plain (Sicilia, Southern Italy): dynamics of degradation processes according to the hydrochemical characteristics of groundwaters. J Hydrol 307:1-16. doi:10.1016/j.jhydrol.2004.08.037

Carol E, Kruse E, Mas-Pla J (2009) Hydrochemical and isotopical evidence of ground water salinization processes on the coastal plain of Samborombón Bay, Argentina. J Hydrol 365:335-345. doi:10.1016/j.jhydrol.2008.11.041

Cullimore DR (2008) Practical manual of groundwater microbiology, 2nd edn. CRC Press, Taylor \& Francis Group, Boca Raton

de Montety V, Radakovitch O, Vallet-Coulomb C, Blavoux B, Hermitte D, Valles V (2008) Origin of groundwater salinity and hydrogeochemical processes in a confined coastal aquifer: case of the Rhône delta (Southern France). Appl Geochem 23:2337-2349. doi:10.1016/j.apgeochem.2008.03.011

El Yaouti F, El Mandour A, Khattach D, Benavente J, Kaufmann O (2009) Salinization processes in the unconfined aquifer of BouAreg (NE Morocco): a geostatistical, geochemical, and tomographic study. Appl Geochem 24:16-31. doi:10.1016/j.apgeochem. 2008.10.005

Farber E, Vengosh A, Gavrieli I, Marie A, Bullen TD, Mayer B, Polak A, Shavit U (2007) The geochemistry of groundwater resources in the Jordan Valley: the impact of the Rift Valley brines. Appl Geochem 22:494-514. doi:10.1016/j.apgeochem.2006.12.002

Fidelibus MD, Giménez E, Morell I, Tulipano L (1993) Salinization processes in the Castellon Plain aquifer. Study and Modelling of Saltwater Intrusion into Aquifers. CIMNE-UPC, Barcelona pp 267-283

Gattacceca J, Vallet-Coulomb C, Mayer A, Claude C, Radakovitch O, Conchetto E, Hamelin B (2009) Isotopic and geochemical characterization of salinization in the shallow aquifers of a reclaimed subsiding zone: the southern Venice Lagoon coastland. J Hydrol 378:46-61. doi:10.1016/j.jhydrol.2009.09.005

Ghabayen S, McKee M, Kemblowski M (2006) Ionic and isotopic ratios for identification of salinity sources and missing data in the Gaza aquifer. J Hydrol 318:360-373. doi:10.1016/j.jhydrol. 2005.06.041

Gomis-Yagües V, Boluda-Botella N, Ruiz-Beviá F (2000) Gypsum precipitation/dissolution as an explanation of the decrease of sulphate concentration during seawater intrusion. J Hydrol 228:48-55. doi:10.1016/S0022-1694(99)00207-3

Gonfiantini R, Araguás L (1988) Los isótopos ambientales en el estudio de la intrusión marina. Simposio Internacional Tecnología de la Intrusión en Acuíferos Costeros, IGME, pp 135-190

Jorreto S, Pulido-Bosch A, Gisbert J, Sánchez-Martos F, Francés I (2009) The freshwater-seawater contact in coastal aquifers supporting intensive pumped seawater extractions: a case study. C R Geosci 341:993-2002. doi:10.016/J.CRTE.2009.08.001
Kass A, Gavrieli I, Yechieli Y, Vengosh A, Starinsky A (2005) The impact of freshwater and wastewater irrigation on the chemistry of shallow groundwater: a case study from the Israeli Coastal Aquifer. J Hydrol 300:314-331. doi:10.1016/j.jhydrol.2004.06.013

Khublaryan MG, Frolov AP, Yushmanov IO (2008) Sea water intrusion in coastal aquifer. Water Resour 35(3):274-286. doi: 10.1134/S0097807808030032

Kim Y, Lee KS, Koh DC, Lee DH, Lee SG, Park WB, Koh GW, Woo NC (2003) Hydrogeochemical and isotopic evidence of groundwater salinization in a coastal aquifer: a case study in Jeju volcanic island, Korea. J Hydrol 270:282-294

Lázaro R, Rodrigo FS, Gutiérrez L, Domingo F, Puigdefábregas J (2001) Analysis of a 30 years rainfall record (1967-1997) in semi-arid SE Spain for implications on vegetation. J Arid Environ 48:373-395. doi:10.1006/jare.2000.0755

Ma F, Yang YS, Yuan R, Cai Z, Pan S (2007) Study of shallow groundwater quality evolution under saline intrusion with environmental isotopes and geochemistry. Environ Geol 51: 1009-1017. doi:10.1007/s00254-006-0370-6

Magaritz M, Luzier JE (1985) Water-rock interactions and seawaterfreshwater mixing effects in the coastal dunes aquifer, Coos Bay, Oregon. Geochim Cosmochim Acta 49:2515-2525. doi:10.1016/ 0016-7037(85)90119-X

Magaritz AM, Goldenberg L, Kafri U, Arad A (1980) Dolomite formation in the seawater-freshwater interface. Nature 287:622624

Martinez DE, Bocanegra EM (2002) Hydrogeochemistry and cationexchange processes in the coastal aquifer of Mar Del Plata, Argentina. Hydrogeol J 10:393-408. doi:10.1007/s10040-0020195-7

Panteleit B, Hamer K, Kringel R, Kessels W, Schulz HD (2011) Geochemical processes in the saltwater-freshwater transition zone: comparing results of a sand tank experiment with field data. Environ Earth Sci 62:77-91. doi:10.1007/s12665-0100499-1

Parkhurst DL, Appelo CAJ (1999) User's guide to PHREEQC (version 2) - A computer program for speciation, batch-reaction, one-dimensional transport, and inverse geochemical calculations. US Geol Surv Water Resour Invest Rep 99-4259

Pulido-Bosch A, Sánchez-Martos F, Martínez-Vidal JL, Navarrete F (1992) Groundwater problems in a semiarid area (Low Andarax river, Almeria, Spain). Environ Geol 20:195-204. doi:10.1007/ BF01706162

Pulido-Bosch A, Delgado J, Sola F, Vallejos A, Vicente F, LópezSánchez JM, Mallorquí J (2011) Identification of potential subsidence related to pumping in the Almería basin (SE Spain). Hydrol Process. doi:10.1002/hyp.8181

Pulido-Leboeuf P (2004) Seawater intrusion and associated processes in a small coastal complex aquifer (Castell de Ferro, Spain). Appl Geochem 19:1517-1527. doi:10.1016/j.apgeochem.2004. 02.004

Rosenthal E, Vinokurov A, Ronen D, Magaritz M, Moshkovitz S (1992) Anthropogenically induced salinization of groundwater: a case study from the Coastal Plain aquifer of Israel. J Contam Hydrol 11:149-171

Sánchez-Martos F, Pulido-Bosch A, Molina-Sánchez L, VallejosIzquierdo A (2002a) Identification of the origin of salinization in groundwater using minor ions (Lower Andarax, Southeast Spain). Sci Total Environ 297:43-58. doi:10.1016/S0048-9697 (01)01011-7

Sánchez-Martos F, Aguilera PA, Garrido-Frenich A, Torres JA, Pulido-Bosch A (2002b) Assessment of groundwater quality by means of self-organizing maps: application in a semiarid area. Environ Manag 30:716-726. doi:10.1007/s00267-2746-z

Schiavo M, Hauser S, Povinec P (2009) Stable isotopes of water as a tool to study groundwater-seawater interactions in coastal 
south-eastern Sicily. J Hydrol 364:40-49. doi:10.1016/ j.jhydrol.2008.10.005

Sivan O, Yechieli Y, Herut B, Lazar B (2005) Geochemical evolution and timescale of seawater intrusion into the coastal aquifer of Israel. Geochim Cosmochim Acta 69:579-592. doi:10.1016/ j.gca.2004.07.023

Vengosh A, Spivack AJ, Artzi Y, Ayalon A (1999) Geochemical and boron, strontium, and oxygen isotopic constraints on the origin of the salinity in groundwater from the Mediterranean coast of Israel. Water Resour Res 35:1877-1894. doi:10.1029/1999 WR900024
Xue Y, Wu J, Ye S, Zhang Y (2000) Hydrogeological and hydrogeochemical studies for salt water intrusion on the South Coast of Laizhou Bay, China. Ground Water 38:38-45. doi: 10.1111/j.1745-6584.2000.tb00200.x

Yamanaka M, Kumagai Y (2006) Sulphur isotope constraint on the provenance of salinity in a confined aquifer system of the southwestern Nobi Plain, central Japan. J Hydrol 325:35-55. doi: 10.1016/j.jhydrol.2005.09.026 